\title{
Nancy Fraser i kritikkens landskap
}

Af Cathrine Holst

Trenger feministisk kritikk en moralfilosofisk begrunnelse? Nei, mente Nancy Fraser $i$ sine tidligere arbeider, hvor hun forsvarte en 'sosial kritikk uten filosofi'. Nå har Fraser endret oppfatning.

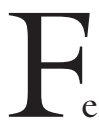

eministisk forskning beskrives ofte, både av utøverne selv og av andre, som en kritisk virksomhet. På 1970tallet var det vanlig at feminister knyttet sin forskergjerning til aktiviteten i kvinnebevegelsen og andre samfunnskritiske bevegelser: De samfunnskritiske bevegelser ble betraktet som sentrale 'oppdragsgivere' for den feministiske forskningen. Båndene mellom forskning og bevegelser ble gradvis mindre tette de påfølgende tiår. Ideen om feministisk forskning som en 'kritisk kunnskapspraksis'l er imidlertid langt fra forlatt; den lever i beste velgående, også i dag, etter forskningsfeltets avpolitisering. ${ }^{2}$ Den feministiske forskning bør, på en eller annen måte, være kritisk - feministiske teoretikere strides om annet, men ikke om dette. $^{3}$

Spørsmålet er hva dette egentlig betyr. Hva gjør en virksomhet kritisk? Hva betyr det egentlig å utøve kritikk? Kritikk er kunsten å felle dommer på en begrunnet måte, oppsummerer Reinhart Koselleck 
(1973) sin gjennomgang av kritikkbegrepets historie: Kritikeren - hun som kan kunsten å kritisere - feller grunngitte dommer om noe, for eksempel teorier, institusjoner, levemåter eller kunstverk.

I denne artikkelen er det særlig dommer om rett og godt som kommer til å oppta meg. Feministiske forskere feller, i likhet med andre forskere, stadig dommer om rett og godt i sine forskningsarbeider - selv om dommene ikke alltid fremkommer like eksplisitt. ${ }^{4}$ Jeg vil i artikkelens del I gå igjennom noen ulike måter å felle slike dommer på; noen ulike kritikktyper. I del II plasserer jeg et knippe feministiske teoretikere i forhold til denne typologien: Hva kjennetegner deres måte å kritisere på? Hva er deres tilnærming til spørsmål om rett og godt? Del III er viet den amerikanske feministiske teoretikeren Nancy Fraser. Fraser har i flere arbeider presentert og drøftet den feministiske kritikkens grunnlag. Jeg diskuterer Frasers arbeider i forhold til de ulike kritikktypene, og argumenterer for at hun $\mathrm{i}$ sine senere bidrag 5 introduserer feministisk kritikk som en moralfilosofisk begrunnet kritikk, mens hun tidligere avviste denne kritikktypens relevans for feminismen. Avslutningsvis, i artikkelens del IV, peker jeg på noen konsekvenser av Frasers skifte.

\section{(I) KritikK: EN TyPOLOGI}

Hvordan tilnærme seg spørsmål om rett og godt? Jeg vil i det følgende presentere seks mulige tilnærminger; seks ulike kritikktyper. Det er, for det forste, den pragmatiske kritikk, for det andre, den teknokratiske kritikk, for det tredje, den immanente kritikk, for det fjerde, kritikk med utgangspunkt i reelle motsigelser, for det femte, kritikk av sosiale patologier, og, for det sjette, en moralfilosofisk begrunnet kritikk. Disse kritikktypene tilnærmer seg spørsmålet om hva som er rett og godt ulikt. De må imidlertid betraktes som idealtypiske tilnærminger, og er således ikke nødvendigvis gjensidig utelukkende. Man kan, uten mot- sigelse, forsvare betydningen av flere av kritikktypene.

Pragmatisk kritikk. Den pragmatiske kritiker mener vitenskapen kan gi oss instrumentell kunnskap: Forskeren kan og bør felle instrumentelle dommer, om hvilke midler som mest effektivt kan bidra til å realisere de mål vi til enhver tid måtte ha satt oss. Få vil benekte at i det minste én av forskningens sentrale oppgaver er å tilveiebringe instrumentell kunnskap. To som har skrevet klargjørende om denne dimensjonen ved vitenskapelig virke, er Max Weber og Karl Popper; en som fortsetter å gjøre det, er Richard Rorty. Hvilke mål vi bør forfølge og hvilke normer vi bør la oss forplikte av, er imidlertid noe som ligger bortenfor en rasjonell begrunnelse, noe som i siste instans er gjenstand for en beslutning, ifølge den pragmatiske kritiker Weber, Popper og Rorty er alle i denne forstand desisjonister. Det vi, ifølge Weber, kan håpe på, er en vitenskap som hjelper oss å finne midler til å nå gitte mål, og som gjør oss i stand til å vurdere konsekvensene av ulike valg av midler og mål. Den samme innfallsvinkelen finnes hos Popper. Popper kombinerer sin desisjonisme med en tro på vitenskap som sosial ingeniørkunst, en vitenskap som stykkevis og gjennom prøving og feiling finner frem til midlene som mest adekvat bringer oss dit vi vil (eller ikke bringer oss dit vi ikke vil). Hos Rorty (1989) finner vi tilsvarende: Den gode vitenskap stiller seg til rådighet for det liberale samfunns 'sosiale ingeniørkunst' og reform-politiske 'eksperimentalisme'.

Teknokratisk kritikk. Den teknokratiske kritiker mener vi gjennom vitenskapelig virksomhet ikke bare kan tilegne oss instrumentell kunnskap, men også kunnskap om hvilke mål vi bør forfølge. Det mener hun, fordi hun rett og slett ikke skiller mellom spørsmål knyttet til hvilke midler som best realiserer våre mål og spørsmål knyttet til hvilke mål vi bør sette oss: Det er, i tekno- 
kratens verden, ingen forskjell av betydning mellom er-spørsmål og bør-spørsmål. Teknokraten mener, kort sagt, at vi gjennom vitenskapelige studier av hvordan verden er, også kan komme frem til hvordan vi bør opptre i den: Svar på bør-spørsmål følger av 'sakstvangen'. Mens den pragmatiske kritiker kan sies å være desisjonistisk i tilnærmingen til normer og verdier, kan teknokraten følgelig sies å være scientistisk. Forsøket på å utvikle en vitenskapelig sosialisme er ett eksempel på en slik teknokratisk scientisme. De riktige handlingsmål ville, ifølge de vitenskapelige sosialister, fremkomme gjennom vitenskapelig kartlegging av objektive historiske lover. Om den vitenskapelige sosialisme er tilbakelagt, er den scientistisk-teknokratiske innstilling det ikke. Den gjør seg stadig gjeldende, både i forskning og politikk. 'Saken' selv, enten 'saken' er økonomiske lover, eller biologiske kjønnsforskjeller, hevdes å 'tvinge' oss til å regulere sosiale relasjoner, økonomien eller kjønnsordningen, på bestemte måter.

Immanent kritikk. Den immanente kritikken henter sine normative målestokker fra selve gjenstanden for kritikken. Det vil si: Den som utøver immanent kritikk, forsøker å vise enten at det er inkonsistens innenfor våre symbolsystemer, eller hun forsøker å vise at det er avstand mellom idealer som artikuleres innenfor våre symbolsystemer og det som faktisk foregår i de sosiale praksiser som reguleres av disse symbolsystemene. Utøveren av immanent kritikk er, kort sagt, opptatt av at våre idealer kommer i konflikt, eller hun er opptatt av avstanden mellom våre idealer og virkeligheten; hun er opptatt av normkollisjoner eller av kollisjoner mellom norm og realitet. Et klassisk eksempel på en kritikk med fokus på normkollisjoner, er den marxistiske kritikken av den uomgjengelige konflikten mellom frihetsnormen og likhetsnormen i borgerligliberale samfunn. Om man innenfor rammen av slike samfunn lar seg forplikte av frihetsnormen, vil man komme til å handle i strid med likhetsnormen - og omvendt. Også Weber var opptatt av målkonflikter: Vitenskapens oppgave, i tillegg til å finne de midler som er best egnet til å nå våre mål, var, ifølge Weber, å synliggjøre og avklare eventuelle konflikter mellom våre mål. Også kritikk inspirert av poststrukturalistisk teori, ofte omtalt som dekonstruktiv kritikk, har fokus på det som oppfattes som uomgjengelige normkollisjoner. Jacques Derrida (2002) argumenterer eksempelvis for at det er en uopphevbar konflikt mellom å yte individet rettferdighet som abstrakt rettsperson, lik alle andre individer, og å yte det rettferdighet som konkret person, forskjellig fra alle andre. Den abstrakte rettferdighet undergraver den konkrete rettferdighet - og omvendt.

Et klassisk eksempel på den andre typen av immanent kritikk, den typen av immanent kritikk som fokuserer på kollisjoner, ikke mellom normer, men mellom norm og realitet, er Gunnar Myrdals An American Dilemma (1944). Her skildrer Myrdal konflikten mellom likhetsprinsippet i den amerikanske forfatningen og $\mathrm{i}$ det etos mange amerikanere bekjenner seg til, og rasediskrimineringen $i$ det amerikanske samfunn.

Kritikk med utgangspunkt $i$ reelle motsigelser er opptatt av å kartlegge enten motsigelser i samfunnsstrukturen, kulturelle motsigelser eller hva vi kan kalle kolliderende organisasjonsprinsipper. Marx var opptatt av reelle motsigelser $i$ samfunnsstrukturen; mellom produktivkrefter og produksjonsforhold, mellom basis og overbygning. Disse reelle motsigelsene i samfunnsstrukturen forårsaket sosiale konflikter, ${ }^{6}$ og i siste instans revolusjon. Daniel Bell (1996) er opptatt av kulturelle motsigelser. Han argumenterer for at den generelle velstandsveksten i kjølvannet av kapitalismens fremvekst har frembrakt og alminneliggjort en hedonistisk, massekonsumeristisk kultur, som undergraver kapitalismens kulturelle forutsetning; et etos knyttet til arbeid, flid 
og nøysomhet. Et eksempel på kritikk med fokus på motsigelser mellom ulike organisasjonsprinsipper, er Claus Offes (1985) analyser av spenningene mellom markedet, demokratiet og velferdsstaten i moderne kapitalistiske samfunn.

Kritikk av sosiale patologier identifiserer forvrengninger eller forstyrrelser - patologier - i sosialt liv: Samfunnskritikken skal diagnostisere patologier, og finne terapier, som Seyla Benhabib (1986) uttrykker denne forestillingen om kritikk. Et klassisk eksempel i sosiologien på en innstendig kritiker av sosiale patologier, er Emile Durkheim. I Selvmordet er det egoisme, altruisme og anomi - normløshet - som diagnostiseres som sosiale patologier. En sentral nåtidig representant for programmet om sosiologi som kritikk av sosiale patologier, er Axel Honneth (1985). Honneth posisjonerer sitt program innenfor en sosialfilosofisk tradisjon fra Rousseaus sivilisasjonskritikk, via Marx' form- og fremmedgjøringskritikk, til Jürgen Habermas' (1981) analyse av systemets kolonialisering av livsverden som sosial patologi.

Før jeg går i gang med å redegjøre for den sjette type av kritikk - moralfilosofisk begrunnet kritikk - vil jeg gjerne stoppe opp litt, og si noe, kort, om det mangelfulle ved de fem typene av kritikk jeg har redegjort for hittil. Alle fem typer forutsetter - som all kritikk - visse målestokker: Man vurderer med utgangspunkt i bestemte standarder, for eksempel en rettferdighetsstandard, en godhetsstandard eller en effektivitetsstandard. Et problem kan være at de kritiske målestokkene forblir for implisitte. Et annet problem kan være at målestokkene er inadekvate. Er effektivitet en tilstrekkelig målestokk? Rettferdighet? Hva med godhet? Et tredje problem kan være at målestokkene ikke begrunnes, eller begrunnes mangelfullt. Det er det siste som opptar meg her.

La meg først vende tilbake til den pragmatiske kritikken, forsvaret av en instru- mentelt orientert vitenskap - jeg nevnte Weber, Popper og Rorty som eksempler. Deres analyser er tydelig verdiforankrede. Webers arbeider er etisk bekymrede - hans beskrivelser av moderne byråkratiserte samfunn som 'jernbur' er selvsagt ikke nøytrale. Popper tilkjennegir et intenst etisk engasjement for det åpne og mot det totalitære samfunn i sine arbeider. Et slikt engasjement kan imidlertid ikke begrunnes rasjonelt; det er basert på verdier vi i siste instans må bestemme oss for å legge til grunn, var Webers og Poppers desisjonistiske poeng. Rortys (1998, 2003) poeng er likelydende. Liberale samfunn er andre samfunn overlegne, fastslår han som erklært 'etnosentriker'. Håpet hans er at stadig flere vil velge å dele hans oppfatning. Skal så skje, skal flere bli liberalere ("liberals"), må det liberale samfunns kvaliteter presenteres gjennom kraftfulle 'omskrivninger' ("redescriptions") som beveger sine 'publikum'. For annet enn bevegende språkbruk og 'sosialt håp' har vi ikke å falle tilbake på, ifølge Rorty; etikken er 'uten prinsipper', moralfilosofiske begrunnelser er bortkastede. Spørsmålet er om denne oppfatningen er holdbar. Forsvarerne av en moralfilosofisk begrunnet kritikk forsøker å vise at den ikke er det.

La oss bevege oss videre til den andre typen av kritikk jeg har nevnt, den scientistisk-teknokratiske kritikken. Hvordan forsøker den scientistiske teknokraten å begrunne sine synspunkter på hva som er rett og godt? Ved å henvise til vitenskapelige fakta om hvordan verden er; ved å henvise til 'sakstvangen'. Denne begrunnelsesstrategien er imidlertid uholdbar. Dels hviler den på en logisk brist: Man kan ikke slutte fra beskrivelser av hvordan verden er, til normative anvisninger om hvordan verden bør være, fra er til bør. Dels hviler den på en forfeilet virkelighetsbeskrivelse: Det er også i de mest tvingende situasjoner mulig å gjøre mer enn én ting. Spørsmålet er, blant annet, hva som er rett å gjøre. Her gir teknokraten oss intet svar. 
Den immanente kritikken og kritikken med utgangspunkt i reelle motsigelser kan gi innsikt i normative dilemmaer og spenninger. Problemet er at ingen av disse kritikktypene gir noen tilstrekkelig begrunnede anvisninger for hvordan vi rimeligvis kan handle, og hvorfor vi bør handle nettopp slik, gitt disse dilemmaene og spenningene. For å ta eksempelet med Gunnar Myrdal og An American Dilemma: Om det nå er en konflikt mellom likhetsprinsippet i amerikansk kultur på den ene siden, og rasediskriminerende holdninger på den andre - hva gjør at likhetsprinsippet bør ha forrang? Hva gir likhetsprinsippet gyldighet som den kritiske målestokken? Eller når Claus Offe skriver om motsetninger mellom prinsippene markedet, demokratiet og velferdsstaten er organisert med utgangspunkt i - hvordan bør vi så forholde oss til disse motsetningene? Balansert, skriver Offe - vi må balansere de ulike organisasjonsprinsippene på en rimelig måte. Men, hva mer nøyaktig, er en rimelig balanse? Og hvorfor mener vi en bestemt balanse er rimelig? Hvorfor er i det hele tatt balanse den sentrale kritiske målestokken? Hva er i veien med 'mye' marked, 'lite' demokrati og velferdsstat? Eller 'lite' marked, 'mye' demokrati og stat?

Den femte formen for kritikk jeg har nevnt, kritikk av sosiale patologier, feller derimot klare dommer om det gode liv den etterlater oss ikke ganske enkelt i dilemmaene og motsigelsene. Spørsmålet er hvordan slike dommer kan begrunnes. Samfunnet er sykt. Det trenger terapi. Men hvorfor? Hvordan begrunne slike sterke og åpenbart kontroversielle påstander?

Det er, slik jeg ser det, kun den sjette formen av kritikk, moralfilosofisk begrunnet kritikk, som i tilstrekkelig grad tar begrunnelsesspørsmålet på alvor. ${ }^{7}$ Når utøverne av den moralfilosofisk begrunnede kritikken blir spurt hvorfor hun mener noe er rett eller godt, hvorfor noe er patologisk, annet er lindrende, forsøker hun å eksplisere og grunngi sine normative standarder, enten grunngivelsen er deontologisk, med fokus på det rette (rettferdighet), eller teleologisk, med fokus på det gode (det gode liv). Et eksempel er John Rawls' (1971, 1993) forsøk på å formulere og begrunne upartiske prinsipper for en rettferdig samfunnsorganisering. Et annet er Jürgen Habermas' (1991, 1992, 1999) utvikling av sitt begrep om kommunikativ rasjonalitet til en diskursteori om moral, rett og politikk. Et tredje er Axel Honneths (1995) forsøk på å forankre ideer om kjærlighet, rettferdighet og solidaritet $\mathrm{i}$ antropologisk forankrede forventninger om intersubjektiv anerkjennelse: Han forsøker, som han sier det selv, å basere sin kritikk av sosiale patologier på en 'formell teori om det gode liv'. I motsetning til Habermas og Rawls som forsøker å gi samfunnskritikken en deontologisk begrunnelse, er Honneths tilnærming følgelig teleologisk.

\section{(II) FEMINISTER I KRITIKKENS LANDSKAP}

Hvordan kan feministiske teoretikere plasseres i forhold til denne typologien? La meg kort gi noen eksempler. ${ }^{8}$

Inspirert av blant andre Karl Popper og de amerikanske pragmatister, utvikler $\mathrm{He}$ len Longino $\mathrm{i}$ The Fate of Knowledge (2002) et begrep om pragmatisk kritikk. Den gode vitenskap frembringes gjennom kritisk og verdirelevant granskning og dia$\log$ i forskersamfunnet. Og blant de verdier vitenskapen bør innlemme i sin relevanshorisont er, ifølge Longino, de feministiske, fordi disse inngår i det liberale samfunns egalitære etos, ${ }^{9}$ det etos vi som borgere av liberale samfunn har valgt å slutte oss til. ${ }^{10}$

Feministiske dekonstruktive bidrag inspirert av poststrukturalistisk meningsteori, fremhever betydningen av immanent kritikk med fokus på uopphevbare normkollisjoner. En toneangivende formulering er Judith Butlers (1992).11 I sin programmatiske artikkel om kritikkens grunnlag, "Contingent Foundations: Feminism and the Question 
of 'Postmodernism'", argumenterer hun for at enhver norm om universell inklusjon, substansiell eller prosedural, vil stå i uomgjengelig motstrid til normen (om universell inklusjon) selv.

En kritikk med utgangspunkt i reelle motsigelser formulerer for eksempel den marxistiske feministen Dorothy Smith i sin bok, The Everyday as Problematic. A Feminist Sociology (1987). Det er, ifølge Smith, motsigelser mellom den økonomiske basis og den politiske overbygning; mellom en kapitalistisk økonomi avhengig av kvinners reproduktive arbeid, og politikkens patriarkalske 'styringsrelasjoner' ("the relations of ruling”). Et eksempel på en feministisk patologikritiker er Virginia Held (1993), som argumenterer for å 'transformere' moderne, liberale samfunns 'forvridde' individualistiske konkurransekultur, til en 'feministisk kultur' der mennesker har 'omsorg' for hverandre. Held skriver seg følgelig inn i den omsorgsetiske tradisjonen innenfor feminismen.

Det finnes imidlertid også feminister som formulerer en moralfilosofisk begrunnet kritikk. All kritikk, også den feministiske, forutsetter normative standarder, enten standarden er det liberale samfunns etos (Longino), universell inklusjon (Butler), de patriarkalske styringsrelasjoners opphevelse (Smith), den feministiske omsorgskultur (Held), eller en annen. En moralfilosofisk begrunnet feministisk kritikk ekspliserer og grunngir sine standarder. Seyla Benhabib (1986, 1992) forankrer for eksempel den feministiske kritikken i en kommunikativ etikk inspirert av Habermas' diskursteori. Drucilla Cornell (1996) begrunner den feministiske kritikken med utgangspunkt i Rawls frihetsprinsipp (hans første rettferdighetsprinsipp i $A$ Theory of Justice), Onora O'Neill (2000) forankrer den i Kants autonomiforestilling, Martha Nussbaum (2000) i en av Aristoteles inspirert teori om menneskets evner.

\section{(III) NANCY Fraser OG KRITIKKENS} MORALFILOSOFISKE BEGRUNNELSE

Spørsmålet som opptar meg her er hvordan Nancy Fraser kan plasseres i dette landskapet. Hvordan forholder hun seg til de ulike kritikktypene? Hvordan mener hun den feministiske kritikken bør formuleres? $\mathrm{Og}$ har hennes oppfatning endret seg over tid? Jeg vil forsøke å vise at den har det.

I sine tidlige arbeider er Fraser uttrykkelig opptatt av at feministisk kritikk ikke skal formuleres som en filosofisk begrunnet kritikk. I sin artikkel i Feminism as Critique (1987) gjør hun seg til talskvinne for en 'sosial kritikk uten filosofi': Samfunnskritikken trenger ingen moralfilosofisk begrunnelse.

Hun utvikler sine synspunkter i en artikkelsamling som kommer ut to år senere, Unruly Practices. Power, Discourse and Gender in Contemporary Social Theory. I artikkelen "Solidarity or Singularity? Richard Rorty between Romaticism and Technocracy" kritiserer Fraser Rortys forestilling om at 'sosial ingeniørkunst' kan erstatte 'politisk kamp', 'ekspertstyre' de 'sosiale bevegelser'.

Fraser deler imidlertid Rortys filosofiske synspunkter. Med henvisning til hans Consequences of Pragmatism, forsvarer hun her en "zero-degree pragmatism" som ikke baserer seg på "traditional philosophical concepts like truth and reason, human nature and morality" (Fraser 1989, 106). Rorty kommenterer selv sin disputt med Fraser på følgende vis: "I suspect my differences with Fraser are concrete and political rather than abstract and philosophical" (Rorty 1998, 209). Dette synes å være en presis 'mistanke' hva den tidlige Fraser angår.

I en annen artikkel i Unruly Practices, "What's Critical about Critical Theory? The Case of Habermas and Gender", anlegger Fraser et tilsvarende perspektiv. Kritisk teori trenger ingen 'filosofisk' grunnlegning, understreker hun også her. Hva som gjør den kritiske teori kritisk er utelukkende dens 'politiske' relevans: 
To my mind, no one has yet improved on Marx's 1843 definition of critical theory as 'the self-clarification of the struggles and wishes of the age'. What is so appealing about this definition is its straightforwardly political character. It makes no claim to any special epistemological status but, rather, supposes that with respect to justification there is no philosophically interesting difference between a critical theory and an uncritical one. However, there is, according to this definition, an important political difference. A critical social theory frames its research program and its conceptual framework with an eye to the aims and activities of those oppositional social movements with which it has a partisan, though not uncritical, identification. The question it asks and the models it designs are informed by that identification and interest (Fraser 1989, 113)

Den tidlige Fraser presenterer følgelig en samfunnskritikk fundert i reelle motsigelser i samfunnsstrukturen - der er reelle og 'dype sosiale kløfter' og 'antagonismer', som hun uttrykker det i sin diskusjon med Rorty. 'Sosiale bevegelser' og deres 'politiske kamp' leses som et uttrykk for disse motsigelsene. Og samfunnskritikerens oppgave er å begrepsfeste og fremme, om enn ikke ukritisk, bevegelsenes krav og kritikk. Dette gir samfunnskritikeren, også den feministiske, uavhengighet til å utøve ulike typer av kritikk, det være seg pragmatisk kritikk, immanent kritikk eller patologikritikk. Hun kan vurdere hvilke midler som mest effektivt kan bidra til å fremme de sosiale bevegelsenes mål (pragmatisk kritikk). Hun kan avdekke konflikter mellom målene (immanent kritikk). Og hun kan identifisere og utvikle de sosiale bevegelsers kritikk av det sosiale livs forvrengninger og forstyrrelser (patologikritikk). Kritikerens oppgave er imidlertid $i k k e$, ifølge den tidlige Fraser, og granske denne kritikken fra et moralfilosofisk perspektiv. Det appellerende med Marx' definisjon av kritisk teori er nettopp, som hun skriver, dens 'politiske karakter'.
Den sene Fraser (2003, 13-128) ser det annerledes. Hun som tidligere forsvarte en sosial kritikk uten filosofi, tar nå utgangspunkt i en moralfilosofisk begrunnet teori om rettferdighet. Normen om 'deltagelse på likefot' skal betraktes som en universell norm. Som 'kantianske' moralnormer gjelder den, ifølge Fraser, 'under verdipluralismens betingelser'; den er gyldig for aktører med ulike begreper om det gode liv: Å sikre alle deltagelse på likefot, og den sosiale omfordeling og kulturelle anerkjennelse som er nødvendig for å sikre alle deltagelse på likefot, er et 'moralsk' krav, som kan redegjøres for ved hjelp av 'kantianske' resonnementer. Frasers begrunnelse er følgelig, som hun selv understreker, 'deontologisk og ikke-sekterisk': Normen om deltagelse på likefot skal ikke forstås som et krav forankret i bestemte begreper om selvrealisering eller godhet, som 'den hegelske sedelighets læresetninger'.

Denne deontologiske moralfilosofiske begrunnelsen; etableringen av rettferdighet fremfor selvrealisering, det rette fremfor det gode, som kritikkens målestokk, er hva som, mest fundamentalt, skiller Frasers tilnærming fra Axel Honneths teleologiske tilnærming. Fraser mener Honneth mislykkes i å gi sin kritikk av sosiale patologier en adekvat moralsk begrunnelse. Fremfor hans formelle teori om det gode liv, argumenterer hun for at kritikkens standard, også den feministiske kritikkens standard, er rettferdighet. Hennes nøyaktige filosofiske posisjonering spesifiseres ikke, men hun henviser i generelle vendinger til Rawls' rettferdighetsteori og Habermas' diskursteori om moral, rett og politikk. Kontrasten til den tidlige Fraser er slående. I Unruly Practices er hun uttrykkelig skeptisk til det habermasianske begrunnelsesprogram. I artikkelen "Foucault. A Young Conservative?", er brodden primært rettet mot Michel Foucaults humanisme-kritikk. At det skulle finnes universelt begrunnbare moralnormer, som Habermas argumenterer for, stiller hun seg imidlertid også tvilende til: 
$[\ldots]$ it may turn out that there will be grounds for rejecting, or at least for modifying and resituating, the ideal of autonomy. If feminists succeed in reinterpreting our history so as to link that ideal to the subordination of women, then Habermas's own normative paradigm will not survive unscathed. The broader question about the normative viability of humanism is still open (Fraser, 1989, 53).

Femten år senere plasserer hun sin rettferdighetsteori på humanismens grunn, innenfor Habermas' normative paradigme.

Fraser (2003) understreker imidlertid også betydningen av andre kritikktyper enn den moralfilosofisk begrunnede kritikk. ${ }^{12}$ Hun er fortsatt opptatt av å utøve pragmatisk kritikk; av å vurdere hvilke midler som mest effektivt kan bidra til å fremme målet om å sikre alle deltagelse på likefot. Hun mener for eksempel at visse politiske virkemidler; de 'transformative' virkemidler som retter seg mot underliggende urettferdighetsskapende mekanismer i økonomi og kultur, mer effektivt kan bidra til å realisere dette målet enn 'bekreftende' virkemidler som fokuserer på å bøte på urettferdighet $\mathrm{i}$ etterkant. Fraser har heller ikke forlatt ambisjonen om å bedrive immanent kritikk: Hun er fortsatt opptatt av å avdekke betydningsfulle målkonflikter innenfor feminismen. For eksempel forsøker hun å klargjøre konflikten mellom likhetsfeminismens mål om at kvinner skal bli like menn (noe som innebærer at kjønnsforskjellens betydning oppheves) og forskjellsfeminismens mål om at kvinners forskjellighet skal verdsettes (noe som innebærer at kjønnsforskjellen snarere understrekes). ${ }^{13}$ Ei heller har Fraser oppgitt å drive kritikk med utgangspunkt i reelle motsigelser og av sosiale patologier. Hun er for eksempel fortsatt opptatt av å forankre samfunnskritikken i en analyse av motsigelser mellom klasser og statusgrupper i det kapitalistiske samfunn (kritikk med utgangspunkt i reelle motsigelser). Og hennes kritikk av den kulturelle urettferdighet som legitimerer kamper for 'anerkjennelse' (som kommer i tillegg til den sosiale urettferdighet som legitimerer kamper for 'omfordeling'), kan leses i lys av patologikritikken hun har reist i eldre bidrag, med utgangspunkt i blant annet Habermas' kolonialiserings-tese ${ }^{14}$ og Michel Foucaults kritikk av moderne samfunns normaliserings- og disiplineringsmekanismer. I motsetning til tidligere, understreker Fraser (2003) imidlertid at også denne type kulturkritikk må gis en moralfilosofisk begrunnelse (som må være deontologisk, ikke teleologisk). Nå er hun, i likhet med Benhabib, Cornell, O'Neill og Nussbaum, opptatt av å eksplisere og grunngi sine normative standarder; hun betrakter dem ikke lenger enkelt og greit ("straightforwardly") som politisk gitte i den forstand jeg har redegjort for.

Dette betyr ikke at de ikke er betydningsfulle forskjeller mellom Fraser og disse fire (så vel som mellom disse fire). Det betyr heller ikke at det ikke er betydningsfulle likheter mellom Fraser og for eksempel Judith Butler. De to foretrekker for eksempel begge en feministisk anerkjennelsespolitikk som er innrettet mot å dekonstruere (Butler) eller transformere (Fraser) etablerte identiteter, for eksempel kjønn, fremfor en (identitets)politikk der kampen står om å få kvinneligheten - kvinners tradisjonelle erfaringer, verdier og identiteter verdsatt og anerkjent (Fraser mener som nevnt at 'transformative' politiske virkemidler er mer effektive for å nå målet om å sikre alle deltagelse på likefot enn 'bekreftende' politiske virkemidler). ${ }^{15}$ Butler avviser imidlertid behovet for en moralfilosofisk begrunnet kritikk. Fraser gjør ikke lenger det. Spørsmålet om hvordan en moralfilosofisk begrunnelse best kan formuleres, er et komplisert spørsmål, som bare så vidt har blitt berørt her. ${ }^{16}$ Mitt poeng i denne sammenheng har vært å få frem at Fraser nå, i motsetning til tidligere, deltar i diskusjonen om dette spørsmålet - og fremholder (mot Honneth), en deontologisk begrunnelse fremfor en teleologisk. 


\section{(IV) KonsekVENSER AV Frasers SKIFTE}

Hva så? Hvilken betydning har egentlig Frasers skifte? Skiftet har først og fremst betydning, selvfølgelig, for diskusjonen om hva feministisk kritikk er, og hva dens grunnlag er. I sine tidligere arbeider presenterer Fraser sosial kritikk uten filosofi som i realiteten er en bestemt kombinasjon av kritikktyper (som jeg har forsøkt å vise) som en tredje vei for den feministiske kritiker, mellom på den ene siden den postmoderne feminisme (som hun ofte eksemplifiserer med Butler), og på den andre, en feminisme som legger til grunn at dommer om rett og godt, i siste instans, krever en moralfilosofisk begrunnelse (Benhabib er den Fraser oftest refererer til i denne sammenheng). Det er denne tredje vei i kritikkens landskap Fraser (2003) har forlatt, når hun nå fremholder at kritikken når alt kommer til alt likevel trenger en (deontologisk) moralfilosofisk begrunnelse.

At Fraser skifter oppfatning, betyr ikke at vi andre uten videre bør gjøre det (det kunne jo tenkes at hun tok feil). Hennes skifte bør imidlertid bemerkes når man gjengir hennes posisjon - og det gjøres stadig oftere, også i skandinavisk feministisk debatt, der Fraser har blitt viet betydelig oppmerksomhet de siste årene. Hennes skifte bør også anspore dem som tidligere har latt seg overbevise av Fraser resonnementer (det vil si, som har latt seg overbevise av det hun har vært overbevist om), til å undersøke om de også kan la seg overbevise av det hun nå er overbevist om. Finnes det - som Fraser nå synes å mene - likevel gode grunner for å forsvare feministisk kritikk som en moralfilosofisk begrunnet kritikk? I dagens feministiske teoridebatt, som i høy grad foregår innenfor rammen av postmoderne parametre, synes en del ganske enkelt å forutsette at så ikke er tilfelle, og at dette er noe feministiske teoretikere $\mathrm{i}$ alminnelighet er enige om. Dette er imidlertid ikke riktig. Feministiske teoretikere som Benhabib, Cornell, O’Neill og
Nussbaum har lenge argumentert for en feministisk kritikk 'med filosofi'. Det nye er at de nå făr følge av Fraser.

Frasers skifte - og de grunner som kan fremholdes for dette skiftet - bør således interessere dem som interesserer seg for feministisk teori utover det overfladiske. Mange feministiske forskere, teoriinteresserte eller ikke, har imidlertid verken tid eller anledning til å sette seg inn i feministisk teori utover det overfladiske. Betyr det noe for dem om det er mulig å gi en moralfilosofisk begrunnelse av feministiske krav eller ikke? Er denne artikkelens diskusjoner antydningsvis relevant for den daglige feministisk forskerpraksis ved universiteter og institutter? Jeg tror de er det. La meg avslutningsvis illustrere hvorfor jeg tror det, med utgangspunkt i et eksempel: En feministisk forsker blir bedt om å vurdere konsekvensene av et bestemt tiltak i en bestemt organisasjon (for eksempel et effektiviseringstiltak i en bedrift) - men oppdragsgiver er, viser det seg, ikke opptatt av tiltakets konsekvenser for den kjønnsmessige likestillingen i organisasjonen; for hvorvidt tiltaket fremmer målet om å sikre alle deltagelse på likefot uavhengig av kjønn eller ikke (for å si det med Fraser). Dette stopper imidlertid ikke den feministiske forskeren, som mener det vil være uforsvarlig å ikke ta målet om kjønnsmessig likestilling i betraktning (noe de fleste feministiske forskere trolig vil være enig med henne i). Spørsmålet som da kan bli reist - fra oppdragsgiver, fra forskerkolleger, fra dem hun forsker på, eller fra andre hold - er, naturligvis, hvorfor det er så uforsvarlig å ikke ta dette målet i betraktning (det utføres stadig forskning som ikke tar målet om kjønnsmessig likestilling i betraktning - hvorfor skulle dette være så uforsvarlig?). Muligens kan dette løses relativt enkelt: Organisasjonen vår feministforsker er bedt om å studere, befinner seg kanskje i en stat med en likestillingslov utformet for å sikre kjønnsmessig likestilling. Derfor vil det være uforsvarlig å ikke ta dette i betrakt- 
ning, kan hun forklare; det ville faktisk talt innebære å bryte loven. Men situasjonen er kanskje - som den ofte er - mer komplisert. La oss si at forskeren i dette tilfelle har sitt virke $\mathrm{i}$ en stat der det ikke finnes likestillingslovgivning, eller i en stat der likestillingslovgivningen kunne sies å være mangelfull; den sikrer ikke kvinner samfunnsmessig deltagelse på lik linje med menn, for eksempel fordi visse organisasjoner (for eksempel bedrifter og religiøse organisasjoner) er unntatt fra hele eller deler av likestillingslovgivningen, eller fordi lovgivningen nok sikrer kvinners formelle rettigheter, men ikke den økonomiske uavhengighet og kulturelle anerkjennelse som er nødvendig for fullverdig samfunnsmessig deltagelse. ${ }^{17}$

Hvilke alternativer har vår forsker da? Hun kan selvfølgelig oppgi ambisjonen om å studere tiltakets konsekvenser for den kjønnsmessige likestillingen i organisasjonen, kort sagt, oppgi ambisjonen om å være en feministisk forsker (i hvert fall i dette tilfelle). Hun kan tvinge sin vilje igjennom overfor oppdragsgiver - om hun har makt til å gjøre det (men få feministiske forskere besitter slik makt). Eller hun kan gå argumentativt til verks; hun kan forsøke å begrunne hvorfor kjønnsmessig likestilling er rettferdig, selv om staten hun virker i ikke garanterer kjønnsmessig likestilling verken som norm eller i praksis. Hun kan, kort sagt, fors $ø$ ke å introdusere sin feministiske kritikk som en moralfilosofisk begrunnet kritikk. Men er dette mulig? I praksis, mer eller mindre. I en forskningsrapport må normative diskusjoner (i likhet med for eksempel metodologiske diskusjoner) nødvendigvis bli relativt kortfattede. Spørsmålet i fokus i denne artikkelen har imidlertid vært om slike diskusjoner kan tas $i$ prinsippet. Er det $\mathrm{i}$ det hele tatt et poeng at vår feministiske forsker forsøker? Ja, vil Fraser anno 2003 svare - det er et poeng at hun forsøker. Hvorvidt vår forsker vil få gjennomslag vil selvsagt gjenstå å se; det avhenger av hennes argumenter - er de gode nok? - og det avhenger av, i fall hennes argumenter er gode, om dem hun henvender seg til, for eksempel oppdragsgiver, er motiverte til å la sine vurderinger og handlinger influeres av gode argumenter. Det er ikke alltid tilfelle - men det har skjedd.

\section{Noter}

1. For å sitere tittelen på an antologi som kom ut i Norge i 1999, redigert av Ann Therese Lotherington og Turid Markussen.

2. Begrepet 'avpolitisering' introduseres av Beatrice Halsaa (1996) i en analyse av forholdet mellom kvinnebevegelse og forskning i Norge. 3. Se diskusjonen i kjølvannet av Egeland (2004) i European Journal of Women's Studies for et ferskt eksempel på denne konsensusen.

4. Vitenskapelig virksomhet er aldri verdifri. I Holst (2005) argumenterer jeg for at verdifrihetstesen, selv i mer sofistikerte varianter, er forfeilet. 5. Jeg vil her forholde meg til hennes bidrag i den 'politisk-filosofiske kontroversen' med den tyske sosialfilosofen Axel Honneth, publisert i Fraser \& Honneth (2003). Kontroversen er publisert på engelsk i Redistribution or Recognition? (2003). Verso, London.

6. I tradisjonen fra Marx kan vi snakke om kritikk som kriseteori.

7. Min konklusjon er således motsatt av Kosellecks, som i Kritik und Krise argumenterer mot en moralfilosofisk begrunnet kritikk.

8. Jeg lar den teknokratiske kritikk ligge.

9. Inspirert av John Stuart Mills instrumentelle argument for ytringsfrihet, argumenterer Longino også for at en vitenskap i tråd med feministiske verdier - der kvinner innlemmes på likefot med menn i vitenskapelige undersøkelser og diskusjoner - vil være en bedre vitenskap, det vil si en vitenskap som frembringer teorier som er mer velbekreftede ("better confirmed"): Feministiske verdier bør legges til grunn fordi de er de liberale samfunns verdier, men også av 'sannhets-funksjonelle' hensyn.

10. Tilsvarende synspunkter forsvares av andre feminister inspirert av amerikansk pragmatisme, som Anderson (2003).

11. Et ferskt eksempel på en tilsvarende tilnærming er Mouffe (2003).

12. Kritikktypene er, som nevnt, ikke nødvendigvis gjensidig utelukkende. 
13. Formuleringen av målet om deltagelse på likefot (uavhengig av kjønn) er et forsøk på å overskride denne konflikten.

14. Hans tese om at systemene, markedet og byråkratiet, kolonialiserer livsverden.

15. Deltagelse på likefot kan best sikres ad transformativ vei, slik Fraser ser det, det vil si gjennom en sosialistisk omfordelingspolitikk og en postmoderne anerkjennelsespolitikk. Hun mener Butler har kommet med verdifulle innspill til en postmoderne anerkjennelsespolitikk.

16. Jeg drøfter spørsmålet nærmere i Holst (2005).

17. Skjeie \& Teigen (2003) argumenterer for at for eksempel den norske likestillingslovgivningen er mangelfull i begge disse henseender.

\section{LITTERATUR}

- Anderson, E. (2003) "Feminist Epistemology and Philosophy of Science", Stanford Encyclopedia of Philosophy.

- Bell, D. (1996) The Cultural Contradictions of Capitalism. Basic Books, New York.

- Benhabib, S. (1986) Critique, Norm and Utopia: a Study of the Foundations of Critical Theory. Colombia University Press, New York.

- Benhabib, S. (1992) Autonomi och gemenskap.

Kommunikativ etik, feminism och postmodernism.

Daidalos, Göteborg.

- Benhabib, S. \& D. Cornell red. (1987) Feminism as Critique: Essays on the Politics of Gender in LateCapitalist Societies. Polity Press, Cambridge.

- Butler, J. (1992) "Contingent Foundations:

Feminism and the Question of 'Postmodernism'”, I Feminists Theorize the Political, J. Butler \& J. W. Scott red., Routledge, New York.

- Cornell, D. (1995) The Imaginary Domain. Abortion, Pornography \& Sexual Harassment. Routledge, New York.

- Derrida, J. (2002) Lovens makt: autoritetenes mystiske grunnlag. Spartacus, Oslo.

- Durkheim, E. (2001) Selvmordet: en sosiologisk undersøkelse. Gyldendal, Oslo.

- Egeland, C. (2004) "What's Feminist in Feminist Theory?", European Journal of Women's Studies 11 (2), 177-188.

- Fraser, N. (1989) Unruly Practices: Power, Discourse and Gender in Contemporary Social Theory. Polity Press, Cambridge.

. Fraser, N. \& A. Honneth (2003) Umverteilung oder Anerkennung? Eine politische-philosophische Kontroverse. Suhrkamp, Frankfurt am Main.
- Habermas, J. (1981) Theorie des kommunikativen Handelns. Suhrkamp, Frankfurt am Main.

- Habermas, J. (1991) Erläuterungen zur Diskursethik. Suhrkamp, Frankfurt am Main.

- Habermas, J. (1992) Faktizität und Geltung. Beitrage zur Diskurstheorie des Rechts und des demokratischen Rechtsstaat. Suhrkamp, Frankfurt am Main. - Habermas, J. (1999) Wabrheit und Rechtfertigung: philosophische Aufsätze. Suhrkamp, Frankfurt am Main.

· Halsaa, B. (1996) "I skjæringspunktet mellom fag og politikk", Hun og han. Kjønn i forskning og politikk, red. H. Holter m.fl., 117-140. Pax, Oslo. - Held, V. (1993) Feminist Morality. Transforming Culture, Society, and Politics. The University of Chicago Press, Chicago.

. Holst, C. (2005) Feminism, Epistemology \&

Morality (under publisering).

- Honneth, A. (1985) Kritik der Macht. Reflexionsstufen einer kritischen Gesellschaftstheorie. Suhrkamp, Frankfurt am Main.

- Honneth, A. (1995): The Struggle for Recognition: the Moral Grammar of Social Conflicts. Polity Press, Cambridge.

- Longino, H. (2002) The Fate of Knowledge.

Princeton University Press, Princeton, New Jersey. - Lotherington, A. T. \& T. Markussen red. (1999) Kritisk kunnskapspraksis. Bidrag til feministisk vitenskapsteori. Spartacus, Oslo.

- Koselleck, R. (1973) Kritik und Krise. Eine Studie zur Pathogenese der bürgerlichen Welt. Suhrkamp, Frankfurt am Main.

- Mouffe, C. (2003) The Democratic Paradox. Verso, New York.

- Myrdal, G. (1944) An American Dilemma: the Negro Problem and Modern Democracy. Harper \& Row, New York.

- Nussbaum, M. C. (2000) Women and Human Development. The Capabilities Approach. Cambridge University Press, New York.

- Offe, C. (1985) Disorganized Capitalism: Contemporary Transformations of Work and Politics. Polity Press, Cambridge.

- O’Neill, O. (2000) Bounds of Justice. Cambridge University Press, New York.

- Popper, K. (1995) The Open Society and Its Enemies. Routledge, New York.

- Rawls, J. (1971) A Theory of Justice. The Belknap Press of Harvard University Press, Cambridge, Massachusetts.

- Rawls, J. (1993) Political Liberalism. Colombia University Press, New York.

- Rorty, R. (1989) "Private Irony and Liberal Hope”, i Contingency, Irony, and Solidarity. Cambridge University Press, New York. 
- Rorty, R. (1998) Truth and Progress. Philosophical Papers. Cambridge University Press, New York. - Rorty, R. (2003) Hopp i stället för kunskap.

Daidalos, Göteborg.

. Skjeie, H. \& M. Teigen (2003) Menn imellom.

Gyldendal Akademisk, Oslo.

- Smith, D. (1987) The Everyday as Problematic. A Feminist Sociology

\section{SUMMARY}

In part I of the article I introduce six different notions of social critique. In part II I connect positions in feminist theory to these notions of critique. Part III is a discussion of Nancy Fraser's notion of critique. I argue that Fraser lately has defended feminist critique as a social critique in need of moralphilosphical justification, whereas she previously argued for 'social criticism without philosphy'. In the latter part of the article I elaborate a few implications of Fraser's shift.

Cathrine Holst

førsteamanuensis i samfunnsvitenskapenes vitenskapsteori ved Universitetet i Bergen

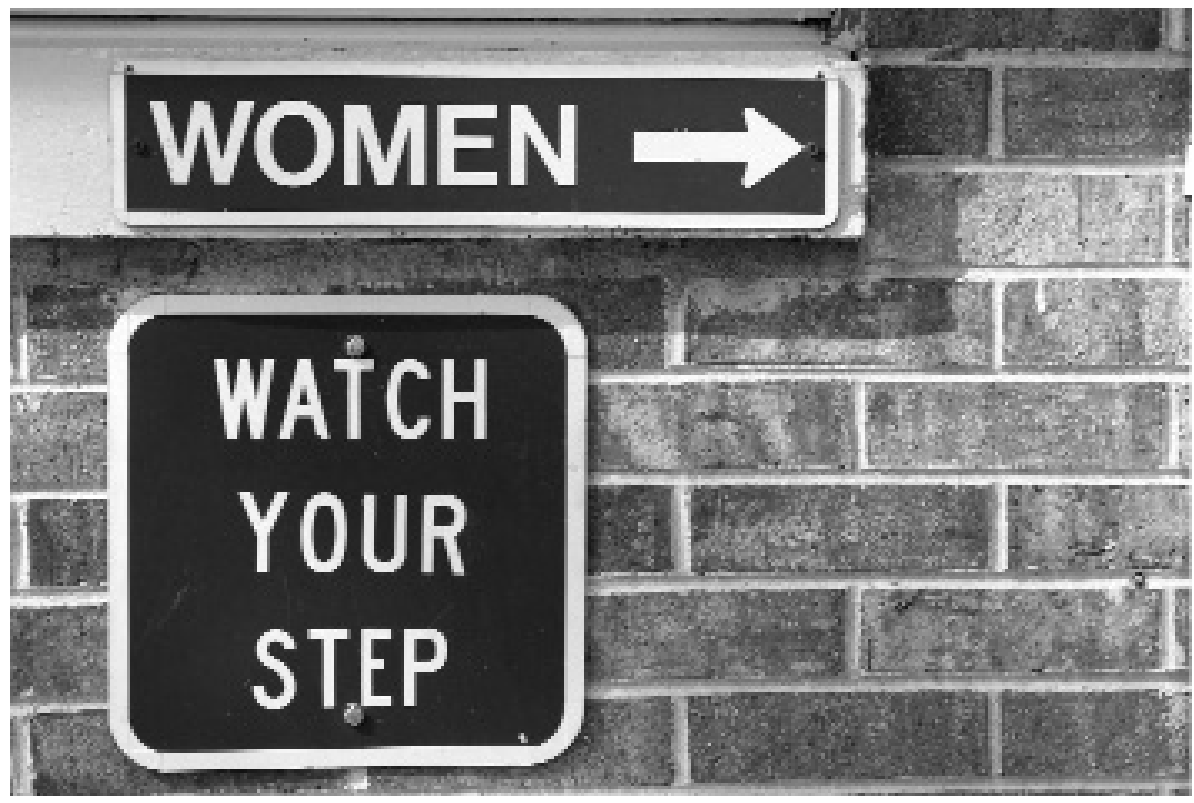

iStockphoto 